\title{
Growth Hormone and Insulin-Like Growth Factor Dysregulation in Pediatric Chronic Kidney Disease
}

\author{
Denver D. Brown ${ }^{a, b} \quad$ Andrew Dauber ${ }^{b, c}$ \\ aDivision of Nephrology, Children's National Hospital, Washington, DC, USA; bepartment of Pediatrics, The George \\ Washington University School of Medicine and Health Sciences, Washington, DC, USA; 'Division of Endocrinology, \\ Children's National Hospital, Washington, DC, USA
}

\section{Keywords}

Growth · Pediatrics · Chronic kidney disease · Growth hormone

\begin{abstract}
Poor growth is a common finding in children with chronic kidney disease (CKD) that has been associated with poor long-term outcomes. The etiology of poor growth in this population is multifactorial and includes dysregulation of the growth hormone $(\mathrm{GH})$ and insulin-like growth factor (IGF) axis. In this review, we describe the data on $\mathrm{GH}$ resistance or insensitivity and inappropriate levels or reduced bioactivity of IGF proposed as contributing factors of growth impairment in children with CKD. Additionally, we describe the theorized negative effect of metabolic acidosis, another frequent finding in pediatric CKD, on the GH/IGF axis and growth. Last, we present the current and potential therapies for the treatment of short stature in pediatric CKD that target the GH/IGF hormonal axis.

(c) 2021 S. Karger AG, Basel
\end{abstract}

\section{Introduction}

Growth impairment or failure is a common comorbidity of pediatric chronic kidney disease (CKD). The current estimates hold that almost one-third of children with
CKD suffer from short stature [1,2]. Growth impairment has been associated with increased mortality, poorer psychosocial functioning, and faster times to adverse posttransplant outcomes [3-5]. Growth failure is a consequence of multiple factors in CKD which include, but are not limited to, the duration of CKD, worsening kidney function, suboptimal nutrition, metabolic acidosis, mineral and bone disorder, and hormonal disturbances [6]. One key hormonal axis that is dysregulated in pediatric CKD is that of the growth hormone $(\mathrm{GH})$ and insulin-like growth factor (IGF) axis. This review will focus on disturbances of the GH/IGF axis thought to contribute to poor growth in children with CKD.

\section{Normal Action of GH/IGF on Bone}

Long bone growth, and thus stature, is primarily determined by action at the growth plate through a process called endochondral ossification. The growth plate lies between the epiphyseal and diaphyseal portions of the long bone and is composed of several zones: (1) the resting zone, (2) the proliferative zone, (3) the hypertrophic zone, and (4) the degenerative zone [7]. Chondrocytes, the predominant cell type found within the growth plate (and various zones), align in a column-like fashion within these zones and parallel to the bone's long axis. Growth karger@karger.com www.karger.com/hrp
(C) 2021 S. Karger AG, Basel

Karger!
Correspondence to:

Denver D. Brown, ddbrown @ childrensnational.org 


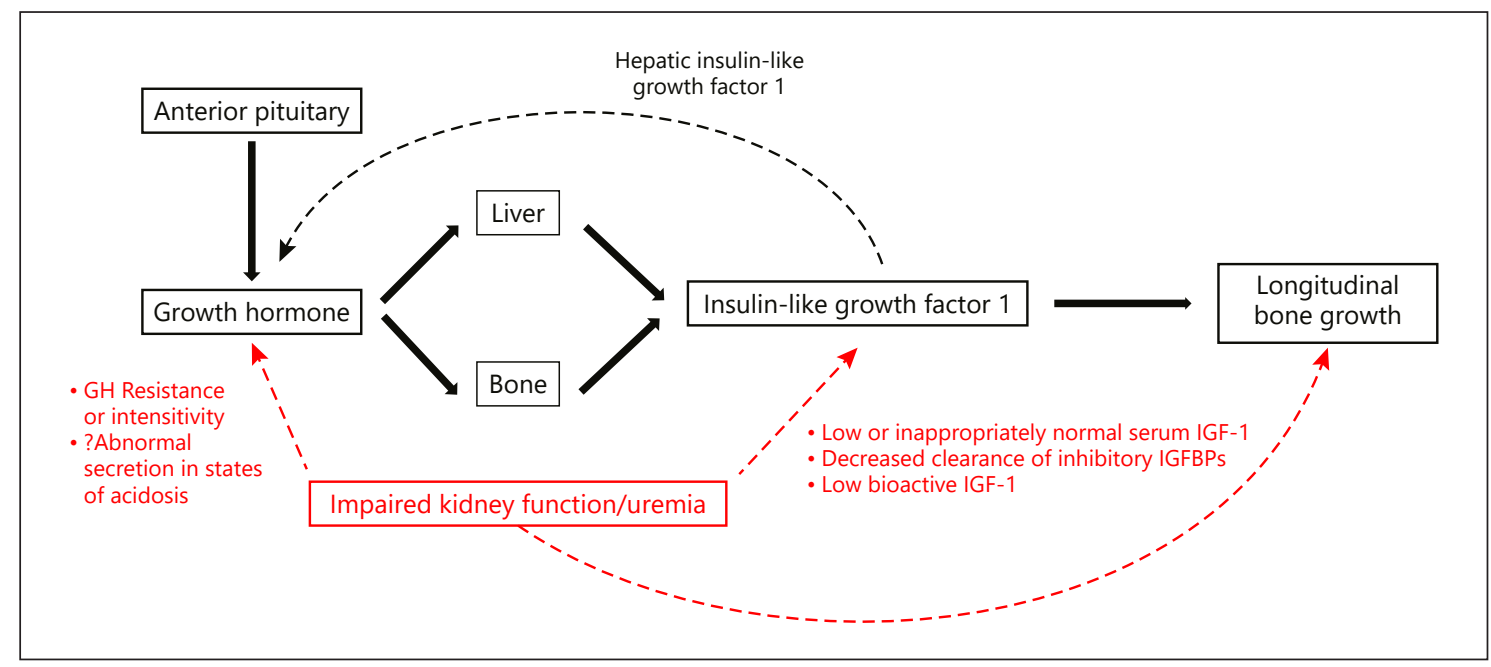

Fig. 1. Normal GH and IGF-1 effects on longitudinal bone growth (black) and perturbations caused by impaired kidney function and uremia (red). Inhibitory effects represented by dashed arrows. GH, growth hormone; IGF, insulin-like growth factor; IGFBP, IGF-binding protein.

of long bones is a result of an increase in the chondrocyte number and size [7]. GH exerts its effects on several different tissue types such as the kidney, liver, and muscle but is generally regarded as the hormone primarily responsible for longitudinal bone growth [8]. It induces cellular differentiation which subsequently leads to the increase in the cellular size and number [9]. Much has been studied about the pathophysiology of the GH's effect on bone growth and mechanisms, including direct effects such as stimulation of prechondrocytes, and indirect effects via stimulation of IGF-1, a hormone known to have paracrine and endocrine effects $[8,10-12]$. IGF-1, a hepatic growth factor, is thought to act on prechondrocytes once they have matured, causing proliferation and hypertrophy, which leads to elongation of the bone $[13,14]$. GH stimulates IGF-1 production both at the liver and locally at the growth plate. IGF-1 also acts to regulate GH by inhibiting its release from the pituitary [12]. Altogether, GH and IGF-1 have been shown to be the key hormonal mediators of chondrocyte proliferation and maturation that lead to subsequent growth in long bones (shown in Fig. 1) and thus longitudinal skeletal growth.

\section{GH/IGF Dysregulation in Pediatric CKD}

\section{GH Resistance (Table 1)}

There are multiple disturbances in the GH/IGF axis noted in children with CKD that are theorized to contrib- ute to the growth failure frequently observed in this population. Aberrations in GH sensitivity is one such cause $[15,16]$. Numerous studies have demonstrated that in patients with impaired kidney function and poor growth, fasting serum GH levels are inappropriately normal or elevated, reflecting a degree of GH insensitivity or resistance $[17,18]$. The normal or increased GH serum concentrations are thought, in part, to be caused by decreased metabolic clearance as a consequence of decreased kidney function as the GH elevation has been shown to be inversely correlated with glomerular filtration $[19,20]$. This theory of $\mathrm{GH}$ resistance is further substantiated by studies of uremic rats that demonstrated decreased hepatic $\mathrm{GH}$ receptor $(G H R)$ mRNA expression and required treatment of the rats with supraphysiologic doses of GH therapy before growth was observed [21-23]. Additional evidence of uremia-induced GH resistance is reflected in studies of children on dialysis who display poor growth, despite treatment with recombinant human GH (rhGH) [24-26]. Similarly, Fischbach et al. [27] found improved growth in children initiated on intensified daily dialysis regimens compared to when they were receiving standard, thrice weekly hemodialysis.

Other investigators posit that GH insensitivity could be related to uremia-induced impairment in hormone signal transduction, particularly the Janus kinase 2 (JAK2)-signal transducer and activator of transcription (STAT) pathway $[28,29]$. In their study comparing rats with surgically induced CKD to controls, with subgroups 
Table 1. Studies demonstrating GH resistance or insensitivity in CKD

\begin{tabular}{|c|c|c|c|}
\hline Schaefer et al. [16] & $\begin{array}{l}43 \text { boys with advanced CRF } \\
\text { (conservative treatment, GFR }<25 \\
\mathrm{~mL} / \mathrm{min} .1 .73 \mathrm{~m}^{2} \text { or dialysis) } \\
38 \text { posttransplant boys } \\
40 \text { healthy boys (control) }\end{array}$ & $\begin{array}{l}\text { Nighttime plasma GH } \\
\text { concentration profile in } \\
\text { peripubertal boys with advanced } \\
\text { CRF }\end{array}$ & $\begin{array}{l}\text { GH hyposecretion is associated with an increase in the } \\
\text { plasma half-life of GH in peripubertal boys with CRF }\end{array}$ \\
\hline Haffner et al. [20] & $\begin{array}{l}\text { Pediatric and adult patients with } \\
\text { CRF }(N=6 \text { children, } N=6 \text { adults }) \\
\text { Healthy adult volunteers }(N=24)\end{array}$ & $\begin{array}{l}\text { Investigate the pharmacokinetics of } \\
(\mathrm{rh}) \mathrm{GH} \\
\text { Determine (rh)GH MCR and } \\
\text { elimination half-life } \\
\text { Determine the effect of GFR on } \\
\text { pharmacokinetics of (rh)GH }\end{array}$ & $\begin{array}{l}\text { In comparison to healthy adults, MCR of rhGH was } \\
\text { diminished by approximately half in CRF participants } \\
\text { Plasma half-life of rhGH was increased by } 25-50 \% \text { in } \\
\text { CRF participants compared to healthy controls } \\
\text { There was an inverse relationship between elimination } \\
\text { half-life of (rh)GH and GFR }\end{array}$ \\
\hline Mehls et al. [21] & $\begin{array}{l}\text { Subtotal nephrectomized rats } \\
\text { Controls rats }\end{array}$ & $\begin{array}{l}\text { Comparison of growth rate after } \\
\text { administration of }(\mathrm{rh}) \mathrm{GH}\end{array}$ & $\begin{array}{l}\text { In uremic rats, normal growth was not achieved after } \\
\text { administration of (rh)GH }\end{array}$ \\
\hline Tönshoff et al. [22] & $\begin{array}{l}\text { Children with CRF }(N=126) \\
\text { Healthy children }(N=773)\end{array}$ & $\begin{array}{l}\text { Comparison of serum GHBP levels/ } \\
\text { GHR expression }\end{array}$ & $\begin{array}{l}\text { In comparison to age- and gender-matched controls, } \\
\text { the majority of CRF patients ( } 77 \% \text { ) had below average } \\
\text { serum GHBP concentrations } \\
\text { Low serum GHBP levels were associated with the } \\
\text { degree of renal dysfunction } \rightarrow \text { the lowest GHBP levels } \\
\text { were observed in children with ESRD } \\
\text { Serum GHBP levels were not affected by } 3 \text { months of } \\
\text { GH therapy }\end{array}$ \\
\hline Tönshoff et al. [23] & $\begin{array}{l}\text { 5/6th nephrectomized rats } \\
\text { Pair-fed controls } \\
\text { Ad libitum-fed controls }\end{array}$ & $\begin{array}{l}\text { Evaluate the effect of uremia on } \\
\text { GHR expression } \\
\text { Evaluate the effect of uremia on } \\
\text { circulating GHBP }\end{array}$ & $\begin{array}{l}\text { Uremic rats demonstrated a } 50 \% \text { decrease in } \\
\text { expression of hepatic GHR mRNA compared to pair- } \\
\text { fed controls } \\
\text { Plasma levels of GHBP in the uremic rats were } \\
\text { significantly higher than levels observed in both } \\
\text { control groups } \\
\text { Treatment with large doses of (rh)GH caused similar } \\
\text { increases in IGF-1 plasma levels in uremic rats and } \\
\text { pair-fed controls indicating that GH insensitivity in } \\
\text { uremia can be overcome by (rh)GH }\end{array}$ \\
\hline Wühl et al. [24] & $\begin{array}{l}\text { Prepubertal CRF }(N=38) \text { and ESRD } \\
(N=18) \text { patients }<10 \text { years old at } \\
\text { initiation of }(\mathrm{rh}) \mathrm{GH} \text { treatment }\end{array}$ & $\begin{array}{l}\text { Evaluate response of CRF and } \\
\text { dialysis patients to (rh)GH }\end{array}$ & $\begin{array}{l}\text { In the first year of treatment, children on dialysis } \\
\text { respond less to (rh)GH compared to CRF patients } \\
\text { The change in height was greater in CRF patients in } \\
\text { year } 2 \text { of treatment as well }\end{array}$ \\
\hline Haffner et al. [25] & $\begin{array}{l}\text { Children with CRF }(N=74) \text { and } \\
\text { ESRD }(N=29) \text { treated with }(\mathrm{rh}) \mathrm{GH}\end{array}$ & $\begin{array}{l}\text { Evaluate effects of short- and long- } \\
\text { term use of (rh)GH in children with } \\
\text { CRF/ESRD and growth impairment }\end{array}$ & $\begin{array}{l}\text { In the CRF children, both standardized height and } \\
\text { predicted adult height were higher than those in the } \\
\text { children on dialysis } \\
\text { GFR positively correlated with height SDS and height } \\
\text { velocity }\end{array}$ \\
\hline Fischbach et al. [27] & $\begin{array}{l}\text { Children with ESRD }(N=5) \text { on } \\
\text { intensified daily dialysis }(4 / 5 \\
\text { children started on }(\mathrm{rh}) \mathrm{GH} \text { before } \\
\text { IDd initiation) }\end{array}$ & $\begin{array}{l}\text { Evaluate linear growth rate in } \\
\text { children before and after initiation } \\
\text { of IDd }\end{array}$ & $\begin{array}{l}\text { Height SDS improved for those children started on (rh) } \\
\text { GH therapy prior to IDd, though change in SDS not } \\
\text { significant } \\
\text { Height SDS significantly increased after conversion to } \\
\text { IDd }\end{array}$ \\
\hline
\end{tabular}


Table 1 (continued)

\begin{tabular}{|c|c|c|c|}
\hline Study & Population & Evaluated outcome(s) & Study finding(s) \\
\hline Schaefer et al. [29] & $\begin{array}{l}\text { 5/6th nephrectomized rats and } \\
\text { pair-fed controls both treated with } \\
\text { (rh)GH }\end{array}$ & $\begin{array}{l}\text { Assess hepatic GH signal } \\
\text { transduction in CRF }\end{array}$ & $\begin{array}{l}\text { CRF rats had significantly decreased levels of GHR } \\
\text { mRNA levels } \\
\text { GH-induced JAK2, STAT5, and STAT3 tyrosine- } \\
\text { phosphorylation was } 75 \% \text { lower in CRF rats } \\
\text { SOCS3 expression was increased by } 2 \text {-fold in CRF rats } \\
\text { treated with GH, and mRNA levels were } 60 \% \text { higher } \\
\text { than those in controls independent of GH treatment }\end{array}$ \\
\hline
\end{tabular}

$\mathrm{CRF}$, chronic renal failure; $\mathrm{CKD}$, chronic kidney disease; ESRD, end-stage renal disease; GH, growth hormone; GHBP, growth hormone binding protein; GFR, glomerular filtration rate; HD, hemodialysis; IDd, intensified daily dialysis; (rh)GH, recombinant growth hormone; SDS, standard deviation score; SOCS, suppressor of cytokine signaling; IGF, insulin-like growth factor; MCR, metabolic clearance rate; GHR, GH receptor; rhGH, recombinant human GH; JAK2, Janus kinase 2; STAT, signal transducer and activator of transcription.

administered GH or buffered solution, Troib et al. [30] found that total JAK2 protein levels in the growth plate were significantly lower in $\mathrm{CKD}$ and $\mathrm{CKD}+\mathrm{GH}$ rats than control groups. Additional findings of that study included decreased growth plate STAT5 phosphorylation (absolute and relative) in basal CKD conditions and significantly increased SOCS2 mRNA levels in the CKD and $\mathrm{CKD}+\mathrm{GH}$ groups. SOCS2 is a known inhibitor of $\mathrm{GH}$ signaling. The contribution of uremia-induced aberrations in JAK-STAT signaling to GH resistance was also studied by Schaefer and colleagues, with their investigation finding diminished phosphorylation of JAK2, STAT1, STAT3, and STAT5 and increased expression of SOCS2 and SOCS3 [29].

Corticosteroids, a common therapeutic agent used for treatment of numerous disorders that lead to CKD, have also been implicated as contributing to $\mathrm{GH}$ resistance and thus growth impairment in children with CKD $[26,31]$. The adverse effects of corticosteroids on GH include stimulating hypothalamic somatostatin-releasing inhibiting factor which, in turn, suppresses pituitary release of $\mathrm{GH}, \mathrm{GH}$ receptor downregulation, and reduction in IGF bioactivity by stimulation of IGF inhibitors [31].

\section{Inappropriate IGF-1 Levels and Reduced Bioactivity}

(Table 2)

During periods of significant growth, the predominant IGF is IGF-1 [32]. While it is synthesized by other tissues, Daughaday et al. [12] proposed that GH stimulates hepatic synthesis and release of IGF-1 (previously named somatomedin), which then exerts linear growthpromoting effects on the growth plate. Based on this idea, also known as the somatomedin hypothesis, increased IGF-1 levels should be seen in children with CKD due to the elevated GH levels found in these patients. However, numerous investigations have demonstrated low IGF-1 levels, or disproportionately low, given increased GH levels, in states of uremia including, explicitly in children with kidney failure [33-36]. The etiology of this may be low production, as a consequence of $\mathrm{GH}$ insensitivity caused by uremia, or reduced expression of IGF-1 mRNA [36-39]. Inadequate nutrition, including protein restriction which is often an imposed dietary restriction as CKD worsens, has been implicated as one of the contributing causes of IGF-1 mRNA reduction [36, 38, 40].

In addition to the inappropriately normal or reduced total IGF-1, low free (bioactive) IGF-1 levels have been found in children with CKD with studies showing a cor- 
Table 2. Studies demonstrating inappropriate IGF-1 levels and/or reduced bioactivity in CKD

\begin{tabular}{|c|c|c|c|}
\hline Study & Population & Evaluated outcome(s) & Study finding(s) \\
\hline $\begin{array}{l}\text { Hokken-Koelega } \\
\text { et al. [33] }\end{array}$ & $\begin{array}{l}22 \text { prepubertal children with } \\
\text { CRF (GFR }<20 \mathrm{~mL} / \mathrm{min}-1.73 \\
\mathrm{~m}^{2} \text { ) and severe growth } \\
\text { retardation } \\
\text { Prepubertal, healthy, normal } \\
\text { height children controls }\end{array}$ & $\begin{array}{l}\text { 24-h plasma GH } \\
\text { profiles secretion } \\
\text { Plasma IGF-I and IGF- } \\
\text { II levels }\end{array}$ & $\begin{array}{l}\text { A normal } 24 \text {-h GH profile was noted in fourteen children, a low } 24-\mathrm{h} \\
\text { GH profile was noted in } 4 \text { children, and an elevated } 24 \text {-h GH profile } \\
\text { was noted in } 4 \text { children } \\
24 \text {-h urinary GH excretion was } 100-1,000 \times \text { higher in all patients with } \\
\text { renal insufficiency than in controls } \\
\text { When grouped by } 24 \text {-h GH profiles, the lowest IGF-I levels were } \\
\text { found in patients with elevated profiles (for bone age), children with } \\
\text { normal profiles had the highest IGF-I levels } \\
\text { There was no correlation between IGF-II levels and GH secretion } \\
\text { profiles }\end{array}$ \\
\hline
\end{tabular}

\begin{tabular}{lll}
\hline Blum et al. [34] & 31 children with ESRD & Assess IGF and IGFBP \\
& 11 children with CRF and & levels in uremia
\end{tabular}

IGFBP accumulates in states of uremia

Excess IGFBP led to binding of free IGF, causing reduced bioactivity In uremic states, there is reduced IGF secretion (indicating a uremic induced $\mathrm{GH}$ resistance)

\begin{tabular}{lll}
\hline Tönshoff et al. [35] & 54 children with ESRD & $\begin{array}{l}\text { Assessing IGF-1 and }-2 \\
\text { and IGFBP-1, -2, and } \\
\text { levels }\end{array}$ \\
& & \\
\hline Tönshoff et al. [36] & $\begin{array}{l}\text { 5/6th nephrectomized rats } \\
\text { Pair-fed controls } \\
\text { Ad libitum-fed controls }\end{array}$ & $\begin{array}{l}\text { Assess IGF-I and } \\
\text { IGFBPs production } \\
\text { rates in CRF }\end{array}$ \\
& &
\end{tabular}

IGF-1 levels were below mean age-related values

IGF-2 levels were at the upper limit of normal to elevated

IGFBP-1, -2, and -3 levels were all increased

IGFBP-3 declined with transplantation and associated increase in kidney function

Compared to ad lib control, hepatic IGF-I gene expression was markedly reduced in uremic rats $(37 \pm 5 \%$ of control) and pair-fed rats (65 $\pm 10 \%$ of control)

The concentration of IGFBPs in the plasma of uremic rats was increased

\begin{tabular}{|c|c|c|c|}
\hline Blum et al. [37] & $\begin{array}{l}51 \text { children with ESRD } \\
11 \text { children with CRF } \\
\text { Healthy controls }\end{array}$ & $\begin{array}{l}\text { Evaluate levels of IGF-1 } \\
\text { and }-2 \text { and IGFBP } 1,-2 \text {, } \\
\text { and }-3\end{array}$ & $\begin{array}{l}\text { Uremic children had significant elevation in all IGFBPs } \\
\text { Despite normal GH secretion, IGF production is lower in uremic } \\
\text { children by } 2 \text { orders of magnitude }\end{array}$ \\
\hline Chan et al. [38] & $\begin{array}{l}5 / 6 \text { th nephrectomized rats } \\
\text { Control rats (sham operated) } \\
\text { Pair-fed controls rats }\end{array}$ & $\begin{array}{l}\text { Evaluation of IGF-1 } \\
\text { levels in response to } \\
\text { (rh)GH administration }\end{array}$ & $\begin{array}{l}\text { Steady-state hepatic IGF-1 mRNA levels were lower in uremic rats } \\
\text { than controls } \\
\text { After (rh)GH administration, there was a lack of significant increase } \\
\text { in hepatic IGF-1 mRNA in uremic rats and pair-fed controls }\end{array}$ \\
\hline Hanna et al. [39] & $\begin{array}{l}5 / 6 \text { th nephrectomized rats }(N= \\
12) \text { treated with }(\mathrm{rh}) \mathrm{GH}(N= \\
\text { 6) versus saline }(N=6) \\
\text { Control rats (sham operated; } \\
N=4)\end{array}$ & $\begin{array}{l}\text { Evaluate molecular } \\
\text { mechanisms of } \\
\text { longitudinal growth in } \\
\text { uremia including (rh) } \\
\text { GH effect on IGF-1 } \\
\text { expression }\end{array}$ & $\begin{array}{l}\text { Compared to controls, uremic rats had lower IGF- } 1 \text { mRNA in the } \\
\text { chondrocytes found in both the proliferative and hypertrophic zones } \\
\text { of their tibial growth plates } \\
\text { Treatment with (rh)GH increased chondrocyte IGF-1 mRNA in } \\
\text { uremic rats, but its abundance was lower than that in controls }\end{array}$ \\
\hline $\begin{array}{l}\text { VandeHaar et al. } \\
{[40]}\end{array}$ & $\begin{array}{l}\text { Female rats fed a } 15 \% \text { protein- } \\
\text { sufficient diet } \\
\text { Female rate fed a } 5 \% \text { protein- } \\
\text { deficient diet }\end{array}$ & $\begin{array}{l}\text { Assess the effect of a } \\
\text { low protein diet on } \\
\text { serum IGF-1 levels and } \\
\text { hepatic IGF-1 mRNA } \\
\text { levels }\end{array}$ & $\begin{array}{l}\text { Serum levels and hepatic mRNA levels were highly correlated } \\
\text { Compared to controls, both serum and hepatic mRNA IGF-1 were } \\
\text { lower in rats on the protein-restricted diet }\end{array}$ \\
\hline Frystyk et al. [41] & $\begin{array}{l}\text { Children with nondialysis- } \\
\text { dependent CRF stage III-V } \\
(N=25) \\
\text { Healthy controls }(N=13)\end{array}$ & $\begin{array}{l}\text { Evaluate alterations in } \\
\text { free IGF-1 in children } \\
\text { with CRF }\end{array}$ & $\begin{array}{l}\text { Children with CRF had lower free IGF-1 levels } \\
\text { There was a positive correlation between degree of kidney function } \\
\text { (creatinine clearance) and free serum IGF-1 levels }\end{array}$ \\
\hline Kiepe et al. [42] & $\begin{array}{l}\text { Cultured rat growth plate } \\
\text { chondrocytes }\end{array}$ & $\begin{array}{l}\text { Investigate the effect of } \\
\text { IGFBP-1, }-2,-3 \text {, and }-6 \\
\text { on IGF-1 binding } \\
\text { cultured chondrocytes }\end{array}$ & $\begin{array}{l}\text { DNA synthesis and cell production of IGF-dependent chondrocytes } \\
\text { were decreased by IGFBP-1, }-2 \text {, and - } 6 \\
\text { If preincubated with chondrocytes, IGFBP- } 3 \text { increased IGF-1 activity } \\
\text { (because it associates with the cell membrane under preincubation } \\
\text { conditions) } \\
\text { If co-incubated with chondrocytes, IGFBP-3 inhibited IGF-1 } \\
\text { induction of chondrocytes }\end{array}$ \\
\hline
\end{tabular}


Table 2 (continued)

\begin{tabular}{|c|c|c|c|}
\hline Study & Population & Evaluated outcome(s) & Study finding(s) \\
\hline Ulinski et al. [43] & $\begin{array}{l}80 \text { children with CRF } \\
9 \text { children with ESRD } \\
32 \text { healthy controls }\end{array}$ & $\begin{array}{l}\text { Assess the effect of } \\
\text { serum IGFBP- } 4 \text {, and }-5 \\
\text { levels on IGF activity in } \\
\text { children with CRF }\end{array}$ & $\begin{array}{l}\text { Compared to healthy prepubertal controls, IGFBP- } 4 \text { levels were } \\
\text { fourfold higher in prepubertal children with CRF/ESRD } \\
\text { There was an inverse correlation between serum IGFBP- } 4 \text { levels (but } \\
\text { not IGFBP-5 levels) and GFR } \\
\text { There was an inverse correlation between standardized height and } \\
\text { IGFBP-4 in prepubertal children with CRF } \\
\text { IGFBP-5 levels did not differ significantly between CRF children and } \\
\text { controls } \\
\text { In CRF children, IGFBP-5 positively correlated with IGF-1 levels, } \\
\text { height measurements, and its level increased with (rh)GH } \\
\text { administration, suggesting it may be a growth stimulatory IGFBP in } \\
\text { CRF }\end{array}$ \\
\hline Tönshoff et al. [44] & $\begin{array}{l}94 \text { children with CRF } \\
68 \text { prepubertal healthy controls } \\
\text { (age matched to the } 54 \\
\text { prepuberal children with CRF) }\end{array}$ & $\begin{array}{l}\text { Quantifying serum } \\
\text { levels of IGF-1 and -2 } \\
\text { and IGFBP-1, -2, and -3 } \\
\text { Results compared to } \\
\text { age-normal values }\end{array}$ & $\begin{array}{l}\text { Serum IGF-1 and - } 2 \text { were largely normal throughout childhood } \\
\text { There was a weaker correlation between IGF- } 1 \text { levels and height in } \\
\text { prepubertal children with CRF than that in controls } \\
\text { CRF children had mild elevation in IGFBP-1 and markedly increased } \\
\text { IGFBP- } 2 \text { and - } 3 \\
\text { There was an inverse correlation between GFR and IGFBP-1, }-2 \text {, and } \\
-3\end{array}$ \\
\hline Durham et al. [45] & $\begin{array}{l}\text { Prepubertal children with CRF/ } \\
\text { ESRD with height }<5 \%\end{array}$ & $\begin{array}{l}\text { Describe the serum } \\
\text { bioactivity of IGFBP-3 } \\
\text { in the } \sim 35 \mathrm{KD} \text { fraction } \\
\text { of serum }\end{array}$ & $\begin{array}{l}\text { The } 29-\text { KD form of IGFBP-3 (IGFBP-3 } 3^{(29)} \text { ), a glycosylated fragment, } \\
\text { predominates in } \sim 35-\text { KD serum fractions in growth-impaired } \\
\text { children with CRF } \\
\text { IGFBP-3 }{ }^{(29)} \text { did not alter IGF-1 activity and mildly inhibited IGF-2 }\end{array}$ \\
\hline Powell et al. [46] & $\begin{array}{l}44 \text { prepubertal children with } \\
\text { CRF and short stature } \\
\text { randomized to treatment with } \\
(\text { rh)GH }(N=30) \text { versus no } \\
\text { treatment }(N=14) \\
10 \text { healthy prepubertal controls }\end{array}$ & $\begin{array}{l}\text { Assessment of serum } \\
\text { IGF and IGFBPs during } \\
\text { treatment with (rh)GH }\end{array}$ & $\begin{array}{l}\text { Baseline levels of IGFBP-1 and -2 levels were higher in children with } \\
\text { CRF than those in controls } \\
\text { Baseline height SDS inversely correlated with IGFBP-2 } \\
\text { At } 12 \text {-month follow-up, compared to untreated children, (rh)GH } \\
\text { treated children had higher height increases, higher serum IGF-1 and } \\
\text {-2, free IGF-1, and IGFBP-3 levels but lower IGFBP-1 serum levels } \\
\text { At } 12 \text {-month follow-up, height SDS in treated children positively } \\
\text { correlated with total IGF, IGF-1 and -2, free IGF-1, and IGFBP-3 } \\
\text { levels }\end{array}$ \\
\hline
\end{tabular}

CRF, chronic renal failure; ESRD, end-stage renal disease; GFR, glomerular filtration rate; GH, growth hormone; IGF, insulin-like growth factor; IGFBP, IGF-binding protein; (rh)GH, recombinant growth hormone; SDS, standard deviation score; CKD, chronic kidney disease.

relation with renal function impairment [37, 41]. IGFbinding proteins (IGFBPs), found in circulation, have a high binding affinity for IGF-1 which prevents, or decreases, IGF-1 binding to its signal receptor [28, 37, 42]. Studies of patients with CKD have shown that with reduced kidney function, there may be decreased clearance of IGFBPs which, in turn, leads to decreased free IGF-1 $[36,43,44]$. There are 6 IGFBPs, but it is important to note that not all IGFBPs act similarly, particularly as it pertains to their effects on growth. Elevated levels of IGFBP-1, IGFBP-2, IGFBP-4, and IGFBP- 6 have been reported in children with kidney impairment, as well as elevated fragmented
IGFBP-3 $[18,43-45]$. There is no significant increase in IGFBP-5 with reduced kidney function [43]. Excess IGFBP-1, IGFBP-2, IGFBP-4, and IGFBP-6 have been proposed to have primarily growth inhibitory effects in children with CKD $[42-44,46]$. The action of IGFBP-3 is more unclear with evidence of both negative and stimulatory effects on growth reported $[42,47,48]$. Overall, with excess IGFBPs in circulation caused by reduced kidney clearance, there is reduction of free IGF-1 levels and binding of free IGF-1 to receptors in bone cartilage. This then acts to diminish the normal negative feedback on the hypothalamic and pituitary stimulus of $\mathrm{GH}$ production $[15,32]$. 


\section{Potential Effect of Metabolic Acidosis}

Metabolic acidosis is an early and frequent complication of pediatric CKD affecting approximately one-third of these children $[49,50]$. It is a consequence of decreased ammonia excretion, which accompanies a decline in kidney function or impaired function of renal tubules commonly occurring in children with congenital anomalies of the kidney and urinary tract. There is a paucity of studies investigating the influence of metabolic acidosis on growth, even though nearly all children with renal tubular acidosis, the majority of whom have normal kidney function, exhibit growth restriction [51-54]. However, from the few studies that do exist, perturbations in the GH/IGF axis as a result of metabolic acidosis appears to be one of the primary mechanisms. Using a nonuremic rat model, Challa et al. [55] demonstrated that metabolic acidosis negatively alters $\mathrm{GH}$ secretory patterns. In follow-up studies, Challa and colleagues also posited that acidosis decreases both GHR mRNA and hepatic IGF-I mRNA (and thus IGF-1 production) [55]. Brüngger examined the effects of metabolic acidosis further in 6 "normal" human participants and found reduced IGF-1 serum levels theorized to be related to dampened response to $\mathrm{GH}$ stimulation in states of acidemia [56]. Given the prevalence of metabolic acidosis in pediatric CKD, especially as disease progresses, and widely available treatment for metabolic acidosis, more investigations of its potential adverse effects on growth are needed.

\section{GH/IGF Axis-Targeted Therapies for Growth Impairment in Pediatric CKD}

rhGH is widely used in the pediatric CKD population, including in posttransplant patients as it has been shown to be an effective and safe treatment of short stature in this group [18, 57-61]. It acts to increase serum GH, IGF1 , and IGFBP-5 levels and decrease IGFBP-1 serum concentrations [32, 62]. Haffner and colleagues investigated the long-term height outcomes in prepubertal children with kidney function impairment treated with rhGH and demonstrated that the majority of these children were able to reach near normal adult heights [63]. It should be noted however that children with CKD show better response to rhGH therapy than those children who have progressed to end-stage renal disease [24, 57]. Current consensus guidelines recommend consideration of rhGH therapy early in the course of CKD to increase the likelihood of attaining maximal height potential [57].
While (rh)GH is the only therapeutic agent targeting the GH/IGF axis approved for the treatment of short stature in pediatric patients with kidney impairment, recombinant IGF-1 (rhIGF-1) has been proposed as a potentially beneficial option for these patients, given observed low levels of IGF-1 [64]. Added benefits of rhIGF-1 may be its positive effects on glomerular filtration. In a randomized, double-blinded, placebo-controlled study using a small cohort of adult patients with end-stage renal disease and healthy participants, rhIGF-1 administered in intermittent doses increased inulin clearance, a surrogate of glomerular filtration [65].

Since both disturbances of GH and IGF-1 are described as potential contributors to linear growth restriction in pediatric $\mathrm{CKD}$, combination therapy with rhGH and rhIGF- 1 has also been suggested as a future therapeutic consideration. In female rats that underwent subtotal nephrectomy, Kovács et al. [66] observed additive effects on length when these uremic rats were treated simultaneously with rhGH and rhIGF-1. However, thus far, this concomitant therapy has only been studied in animal models.

\section{Hyperparathyroidism and Mineral and Bone Disorder}

Parathyroid hormone $(\mathrm{PTH})$ overactivation is a key factor in growth failure caused by CKD mineral and bone disorder (MBD). Aberrations in calcium, phosphorus, and vitamin $\mathrm{D}$ balance, as a consequence of chronic and progressive kidney function impairment, drive PTH hyperactivity; this even occurs during early stages of CKD. This secondary hyperparathyroidism subsequently results in increased bone turnover and defects in bone mineralization, causing abnormal architecture of the growth plate which can impair appropriate growth $[67,68]$. While a complete discussion of MBD due to hyperparathyroidism is beyond the scope of this review, it is important to mention a few key pieces of evidence supporting the important role that PTH plays in impairing growth in these children. The relationship between hyperparathyroidism and poor growth in children with CKD has been exemplified in studies where poor PTH control was associated with an increased risk for slipped capital femoral epiphysis in children with chronically impaired kidney function as well as a decreased height standard deviation score (SDS) in children receiving peritoneal dialysis whose PTH average was $>500 \mathrm{pg} / \mathrm{mL}$ [69]. Additional evidence is provided by data demonstrating an association 
between PTH control and an improved height SDS (0.09 SD per year) $[70,71]$. Current CKD management guidelines recommend that in children with severe hyperparathyroidism $(\mathrm{PTH}>500 \mathrm{pg} / \mathrm{mL}), \mathrm{rhGH}$ treatment should be held until appropriate PTH control is achieved [72, 73]. As such, in considering the effects of hormonal dysregulation on growth in children with $\mathrm{CKD}$, and treatment with rhGH in this population, providers should also be mindful of the influence of MBD.

\section{Conclusion}

Perturbations in the GH/IGF axis that contribute to poor growth commonly observed in children with impaired kidney function include GH resistance or insensitivity caused by uremia and low (bioactive) IGF-1, largely as a consequence of decreased renal clearance of IGFBPs (shown in Fig. 1). An understudied area is the contribution of metabolic acidosis to GH/IGF axis dysfunction, but reported effects include adverse alterations in $\mathrm{GH}$ secretion, diminished response to $\mathrm{GH}$ stimulation, and decreased GHR and IGF-1 mRNA. rhGH is safe and effective in treating short stature in children with im- paired kidney function and should be considered early in the course of CKD in order to maximize final height outcomes. Future therapeutic regimens that may prove beneficial to children with CKD and growth restriction may include treatment with rhIGF-1 as monotherapy or concomitantly with rhGH, but more investigations of these regimens are needed.

\section{Conflict of Interest Statement}

A.D. is an associate editor of Hormone Research in Paediatrics.

\section{Funding Sources}

A.D. was supported by the Eunice Kennedy Shriver National Institute of Child Health and Human Development of the National Institutes of Health (Award Number R01HD093622).

\section{Author Contributions}

Dr. Brown and Dr. Dauber both made substantial contributions to the concept, design, and revision of the presented review.

\section{References}

1 Seikaly MG, Salhab N, Gipson D, Yiu V, Stablein D. Stature in children with chronic kidney disease: analysis of NAPRTCS database. Pediatr Nephrol. 2006;21(6):793-9.

2 Rodig NM, McDermott KC, Schneider MF, Hotchkiss HM, Yadin O, Seikaly MG, et al. Growth in children with chronic kidney disease: a report from the Chronic Kidney Disease in Children Study. Pediatr Nephrol. 2014;29(10):1987-95.

3 Wong CS, Gipson DS, Gillen DL, Emerson S, Koepsell T, Sherrard DJ, et al. Anthropometric measures and risk of death in children with end-stage renal disease. Am J Kidney Dis. 2000;36(4):811-9.

4 Gerson AC, Wentz A, Abraham AG, Mendley SR, Hooper SR, Butler RW, et al. Health-related quality of life of children with mild to moderate chronic kidney disease. Pediatrics. 2010; 125(2):e349-57.

5 Al-Uzri A, Matheson M, Gipson DS, Mendley SR, Hooper SR, Yadin O, et al. The impact of short stature on health-related quality of life in children with chronic kidney disease. J Pediatr. 2013;163(3):736-e1.

6 Silverstein DM. Growth and nutrition in pediatric chronic kidney disease. Front Pediatr. 2018;6:205.

7 Pines M, Hurwitz S. The role of the growth plate in longitudinal bone growth. Poult Sci. 1991;70(8):1806-14.
8 Ohlsson C, Bengtsson BA, Isaksson OG, Andreassen TT, Slootweg MC. Growth hormone and bone. Endocr Rev. 1998;19(1):55-79.

9 Liu JL, LeRoith D. Insulin-like growth factor $\mathrm{I}$ is essential for postnatal growth in response to growth hormone. Endocrinology. 1999; 140(11):5178-84.

10 Isaksson OG, Edén S, Jansson JO. Mode of action of pituitary growth hormone on target cells. Annu Rev Physiol. 1985;47:483-99.

11 Lindahl A, Isgaard J, Nilsson A, Isaksson OG. Growth hormone potentiates colony formation of epiphyseal chondrocytes in suspension culture. Endocrinology. 1986;118(5): 1843-8.

12 Daughaday WH, Hall K, Raben MS, Salmon WD Jr, van den Brande JL, van Wyk JJ. Somatomedin: proposed designation for sulphation factor. Nature. 1972;235(5333): 107.

13 Lindahl A, Isgaard J, Carlsson L, Isaksson OG. Differential effects of growth hormone and insulin-like growth factor I on colony formation of epiphyseal chondrocytes in suspension culture in rats of different ages. Endocrinology. 1987;121(3):1061-9.

14 Racine HL, Serrat MA. The actions of IGF-1 in the growth plate and its role in postnatal bone elongation. Curr Osteoporos Rep. 2020; 18(3):210-27.

15 Roelfsema V, Clark RG. The growth hormone and insulin-like growth factor axis: its manip- ulation for the benefit of growth disorders in renal failure. J Am Soc Nephrol. 2001;12(6): 1297-306.

16 Schaefer F, Veldhuis JD, Stanhope R, Jones J, Schärer K. Alterations in growth hormone secretion and clearance in peripubertal boys with chronic renal failure and after renal transplantation. Cooperative Study Group of Pubertal development in Chronic Renal Failure. J Clin Endocrinol Metab. 1994;78(6): 1298-306.

17 Samaan NA, Freeman RM. Growth hormone levels in severe renal failure. Metabolism. 1970;19(2):102-13.

18 Tönshoff B, Kiepe D, Ciarmatori S. Growth hormone/insulin-like growth factor system in children with chronic renal failure. Pediatr Nephrol. 2005;20(3):279-89.

19 Owens D, Srivastava MC, Tompkins CV, Nabarro JD, Sönksen PH. Studies on the metabolic clearance rate, apparent distribution space and plasma half-disappearance time of unlabelled human growth hormone in normal subjects and in patients with liver disease, renal disease, thyroid disease and diabetes mellitus. Eur J Clin Invest. 1973;3(4):284-94.

20 Haffner D, Schaefer F, Girard J, Ritz E, Mehls O. Metabolic clearance of recombinant human growth hormone in health and chronic renal failure. J Clin Invest. 1994;93(3):116371. 
21 Mehls O, Ritz E, Hunziker EB, Eggli P, Heinrich U, Zapf J. Improvement of growth and food utilization by human recombinant growth hormone in uremia. Kidney Int. 1988; 33(1):45-52.

22 Tönshoff B, Cronin MJ, Reichert M, Haffner $\mathrm{D}$, Wingen AM, Blum WF, et al. Reduced concentration of serum growth hormone (GH)-binding protein in children with chronic renal failure: correlation with GH insensitivity. The European Study Group for Nutritional Treatment of Chronic Renal Failure in Childhood. The German Study Group for Growth Hormone Treatment in Chronic Renal Failure. J Clin Endocrinol Metab. 1997; 82(4):1007-13.

23 Tönshoff B, Edén S, Weiser E, Carlsson B, Robinson IC, Blum WF, et al. Reduced hepatic growth hormone $(\mathrm{GH})$ receptor gene expression and increased plasma GH binding protein in experimental uremia. Kidney Int. 1994;45(4):1085-92.

24 Wühl E, Haffner D, Nissel R, Schaefer F, Mehls O. Short dialyzed children respond less to growth hormone than patients prior to dialysis. German Study Group for Growth Hormone Treatment in Chronic Renal Failure. Pediatr Nephrol. 1996;10(3):294-8.

25 Haffner D, Wühl E, Schaefer F, Nissel R, Tönshoff B, Mehls O . Factors predictive of the short- and long-term efficacy of growth hormone treatment in prepubertal children with chronic renal failure. The German Study Group for Growth Hormone Treatment in Chronic Renal Failure. J Am Soc Nephrol. 1998;9(10):1899-907.

26 Mehls O, Wühl E, Tönshoff B, Schaefer F, Nissel R, Haffner D. Growth hormone treatment in short children with chronic kidney disease. Acta Paediatr. 2008;97(9):1159-64.

27 Fischbach M, Terzic J, Menouer S, Dheu C, Soskin S, Helmstetter A, et al. Intensified and daily hemodialysis in children might improve statural growth. Pediatr Nephrol. 2006; 21(11):1746-52.

28 Tönshoff B, Blum WF, Mehls O. Derangements of the somatotropic hormone axis in chronic renal failure. Kidney Int Suppl. 1997; 58:S106-13.

29 Schaefer F, Chen Y, Tsao T, Nouri P, Rabkin R. Impaired JAK-STAT signal transduction contributes to growth hormone resistance in chronic uremia. J Clin Invest. 2001;108(3): $467-75$.

30 Troib A, Landau D, Kachko L, Rabkin R, Segev Y. Epiphyseal growth plate growth hormone receptor signaling is decreased in chronic kidney disease-related growth retardation. Kidney Int. 2013;84(5):940-9.

31 Tönshoff B, Mehls O. Interactions between glucocorticoids and the growth hormone-insulin-like growth factor axis. Pediatr Transplant. 1997;1(2):183-9.

32 Mahesh S, Kaskel F. Growth hormone axis in chronic kidney disease. Pediatr Nephrol. 2008;23(1):41-8.
33 Hokken-Koelega AC, Hackeng WHL, Stijnen T, Wit JM, de Muinck Keizer-Schrama SMPF, Drop SLS. Twenty-four-hour plasma growth hormone $(\mathrm{GH})$ profiles, urinary $\mathrm{GH}$ excretion, and plasma insulin-like growth factor-I and -II levels in prepubertal children with chronic renal insufficiency and severe growth retardation. J Clin Endocrinol Metab. 1990; 71(3):688-95.

34 Blum WF, Ranke MB, Kietzmann K, Tönshoff B, Mehls O. Growth hormone resistance and inhibition of somatomedin activity by excess of insulin-like growth factor binding protein in uraemia. Pediatr Nephrol. 1991;5(4): 539-44.

35 Tönshoff B, Blum WF, Mehls O. Serum insulin-like growth factors and their binding proteins in children with end-stage renal disease. Pediatr Nephrol. 1996;10(3):269-74.

36 Tönshoff B, Powell DR, Zhao D, Durham SK, Coleman ME, Domené HM, et al. Decreased hepatic insulin-like growth factor (IGF)-I and increased IGF binding protein-1 and -2 gene expression in experimental uremia. Endocrinology. 1997;138(3):938-46.

37 Blum WF. Insulin-like growth factors (IGFs) and IGF binding proteins in chronic renal failure: evidence for reduced secretion of IGFs. Acta Paediatr Scand Suppl. 1991;379: 24-32; discussion 32.

38 Chan W, Valerie KC, Chan JC. Expression of insulin-like growth factor-1 in uremic rats: growth hormone resistance and nutritional intake. Kidney Int. 1993;43(4):790-5.

39 Hanna JD, Santos F, Foreman JW, Chan JC, Han VK. Insulin-like growth factor-I gene expression in the tibial epiphyseal growth plate of growth hormone-treated uremic rats. Kidney Int. 1995;47(5):1374-82.

40 VandeHaar MJ, Moats-Staats BM, Davenport ML, Walker JL, Ketelslegers JM, Sharma BK, et al. Reduced serum concentrations of insulin-like growth factor-I (IGF-I) in protein-restricted growing rats are accompanied by reduced IGF-I mRNA levels in liver and skeletal muscle. J Endocrinol. 1991;130(2):305-12.

41 Frystyk J, Ivarsen P, Skjaerbaek C, Flyvbjerg A, Pedersen EB, Orskov H. Serum-free insulin-like growth factor I correlates with clearance in patients with chronic renal failure. Kidney Int. 1999;56(6):2076-84.

42 Kiepe D, Ulinski T, Powell DR, Durham SK, Mehls O, Tönshoff B. Differential effects of insulin-like growth factor binding proteins-1, $-2,-3$, and -6 on cultured growth plate chondrocytes. Kidney Int. 2002;62(5):1591-600.

43 Ulinski T, Mohan S, Kiepe D, Blum WF, Wingen AM, Mehls $\mathrm{O}$, et al. Serum insulin-like growth factor binding protein (IGFBP)-4 and IGFBP-5 in children with chronic renal failure: relationship to growth and glomerular filtration rate. The European Study Group for Nutritional Treatment of Chronic Renal Failure in Childhood. German Study Group for Growth Hormone Treatment in Chronic Renal Failure. Pediatr Nephrol. 2000;14(7):58997.
44 Tönshoff B, Blum WF, Wingen AM, Mehls O. Serum insulin-like growth factors (IGFs) and IGF binding proteins 1,2 , and 3 in children with chronic renal failure: relationship to height and glomerular filtration rate. The European Study Group for Nutritional Treatment of Chronic Renal Failure in Childhood. J Clin Endocrinol Metab. 1995;80(9):268491.

45 Durham SK, Mohan S, Liu F, Baker BK, Lee PD, Hintz RL, et al. Bioactivity of a 29-kilodalton insulin-like growth factor binding protein-3 fragment present in excess in chronic renal failure serum. Pediatr Res. 1997;42(3): 335-41.

46 Powell DR, Liu F, Baker BK, Hintz RL, Lee PD, Durham SK, et al. Modulation of growth factors by growth hormone in children with chronic renal failure. The Southwest Pediatric Nephrology Study Group. Kidney Int. 1997; 51(6):1970-9.

47 Blum WF, Albertsson-Wikland K, Rosberg S, Ranke MB. Serum levels of insulin-like growth factor I (IGF-I) and IGF binding protein 3 reflect spontaneous growth hormone secretion. J Clin Endocrinol Metab. 1993; 76(6):1610-6.

48 Powell DR. Effects of renal failure on the growth hormone-insulin-like growth factor axis. J Pediatr. 1997;131(1 Pt 2):S13-6.

49 Furth SL, Abraham AG, Jerry-Fluker J, Schwartz GJ, Benfield M, Kaskel F, et al. Metabolic abnormalities, cardiovascular disease risk factors, and GFR decline in children with chronic kidney disease. Clin J Am Soc Nephrol. 2011;6(9):2132-40.

50 Brown DD, Roem J, Ng DK, Reidy KJ, Kumar J, Abramowitz MK, et al. Low Serum Bicarbonate and CKD Progression in Children. Clin J Am Soc Nephrol. 2020;15(6):755-65.

51 McSherry E, Morris RC Jr. Attainment and maintenance of normal stature with alkali therapy in infants and children with classic renal tubular acidosis. J Clin Invest. 1978;61(2): 509-27.

52 Caldas A, Broyer M, Dechaux M, Kleinknecht C. Primary distal tubular acidosis in childhood: clinical study and long-term follow-up of 28 patients. J Pediatr. 1992;121(2):233-41.

53 Santos F, Chan JC. Renal tubular acidosis in children. Diagnosis, treatment and prognosis. Am J Nephrol. 1986;6(4):289-95.

54 Sharma AP, Singh RN, Yang C, Sharma RK, Kapoor R, Filler G. Bicarbonate therapy improves growth in children with incomplete distal renal tubular acidosis. Pediatr Nephrol. 2009;24(8):1509-16.

55 Challa A, Krieg RJ Jr, Thabet MA, Veldhuis JD, Chan JC. Metabolic acidosis inhibits growth hormone secretion in rats: mechanism of growth retardation. Am J Physiol. 1993;265(4 Pt 1):E547-53.

56 Brüngger M, Hulter HN, Krapf R. Effect of chronic metabolic acidosis on the growth hormone/IGF-1 endocrine axis: new cause of growth hormone insensitivity in humans. Kidney International. 1997;51(1):216-21. 
57 Mahan JD, Warady BA. Assessment and treatment of short stature in pediatric patients with chronic kidney disease: a consensus statement. Pediatr Nephrol. 2006;21(7):91730.

58 Hokken-Koelega A, Mulder P, De Jong R, Lilien M, Donckerwolcke R, Groothof J. Longterm effects of growth hormone treatment on growth and puberty in patients with chronic renal insufficiency. Pediatr Nephrol. 2000; 14(7):701-6.

59 Fine RN, Ho M, Tejani A, Blethen S. Adverse events with rhGH treatment of patients with chronic renal insufficiency and end-stage renal disease. J Pediatr. 2003;142(5):539-45.

60 Fine RN, Stablein D. Long-term use of recombinant human growth hormone in pediatric allograft recipients: a report of the NAPRTCS Transplant Registry. Pediatr Nephrol. 2005; 20(3):404-8.

61 Müller-Wiefel D, Frisch H, Tulassay T, Bell L, Zadik Z. Treatment of growth failure with growth hormone in children with chronic kidney disease: an open-label long-term study. Clin Nephrol. 2010;74(2):97-105.

62 Powell DR, Durham SK, Brewer ED, Frane JW, Watkins SL, Hogg RJ, et al. Effects of chronic renal failure and growth hormone on serum levels of insulin-like growth factorbinding protein-4 (IGFBP-4) and IGFBP- 5 in children: a report of the Southwest Pediatric Nephrology Study Group. J Clin Endocrinol Metab. 1999;84(2):596-601.

63 Haffner D, Schaefer F, Nissel R, Wühl E, Tönshoff B, Mehls O. Effect of growth hormone treatment on the adult height of children with chronic renal failure. German Study Group for Growth Hormone Treatment in Chronic Renal Failure. N Engl J Med. 2000;343(13):923-30.

64 Clark RG. Recombinant insulin-like growth factor-1 as a therapy for IGF-1 deficiency in renal failure. Pediatr Nephrol. 2005;20(3): 290-4.

65 Vijayan A, Franklin SC, Behrend T, Hammerman MR, Miller SB. Insulin-like growth factor I improves renal function in patients with end-stage chronic renal failure. Am J Physiol. 1999;276(4):R929-34.

66 Kovács GT, Oh J, Kovács J, Tönshoff B, Hunziker EB, Zapf J, et al. Growth promoting effects of growth hormone and IGF-I are additive in experimental uremia. Kidney Int. 1996; 49(5):1413-21.

67 French CB, Genel M. Pathophysiology of growth failure in chronic renal insufficiency. Kidney Int Suppl. 1986;19:S59-64.
68 Kuizon BD, Salusky IB. Cell biology of renal osteodystrophy. Pediatr Nephrol. 2002; 17(10):777-89.

69 Borzych D, Rees L, Ha IS, Chua A, Valles PG, Lipka M, et al. The bone and mineral disorder of children undergoing chronic peritoneal dialysis. Kidney Int. 2010;78(12): 1295-304.

70 Waller S, Ledermann S, Trompeter R, van't Hoff W, Ridout D, Rees L. Catch-up growth with normal parathyroid hormone levels in chronic renal failure. Pediatr Nephrol. 2003; 18(12):1236-41.

71 Waller S. Parathyroid hormone and growth in chronic kidney disease. Pediatr Nephrol. 2011;26(2):195-204.

72 Kidney Disease: Improving Global Outcomes (KDIGO) CKD-MBD Update Work Group. KDIGO 2017 clinical practice guideline update for the diagnosis, evaluation, prevention, and treatment of Chronic Kidney DiseaseMineral and Bone Disorder (CKD-MBD). Kidney Int Suppl. 2017;7(1):1-59.

73 Haffner D, Schaefer F. Searching the optimal PTH target range in children undergoing peritoneal dialysis: new insights from international cohort studies. Pediatr Nephrol. 2013; 28(4):537-45. 